\title{
Peripheral but not central leptin prevents the immunosuppression associated with hypoleptinemia in rats
}

\author{
Y Zhang ${ }^{1,2}$, J T Wilsey ${ }^{2}$, C D Frase ${ }^{1}$, M M Matheny ${ }^{1,2}$, \\ B S Bender ${ }^{1,4}$, S Zolotukhin ${ }^{3}$ and $P$ J Scarpace ${ }^{1,2}$ \\ ${ }^{1}$ Geriatric Research, Education and Clinical Center, Department of Veterans Affairs Medical Center, Gainesville, Florida, USA \\ ${ }^{2}$ Department of Pharmacology and Therapeutics, University of Florida, Gainesville, Florida, USA \\ ${ }^{3}$ Department of Molecular Genetics, University of Florida, Gainesville, Florida, USA \\ ${ }^{4}$ Department of Medicine, Infectious Disease Division, College of Medicine, University of Florida, Gainesville, Florida, USA \\ (Requests for offprints should be addressed to P J Scarpace, Geriatric Research, Education and Clinical Center (182), Department of Veterans Affairs Medical \\ Center, Gainesville, Florida 32608-1197, USA; Email: scarpace@ufl.edu)
}

\begin{abstract}
Leptin is a peripheral immunoenhancing reagent that directly activates splenic lymphocytes in mice. We found that a $48 \mathrm{~h}$ fast in rats resulted in a decrease in serum leptin that was accompanied by a lower delayed-type hypersensitivity (DTH) response. Peripheral leptin replacement completely restored this response in fasted animals. We employed a recombinant adeno-associated virus (rAAV) system to deliver leptin gene directly into rat brain to assess the effect of sustained long-term central expression of leptin on immune responses. The rAAV-leptin rats had elevated central leptin over the 60 day duration of the experiment, whereas body fat and circulating leptin fell to near zero levels. The DTH response was significantly reduced by $10-20 \%$ in rats receiving rAAV-leptin compared with the control rats, and the difference was
\end{abstract}

maintained for over $50 \mathrm{~h}$. When the rats undergoing rAAV-leptin gene therapy were given either murine recombinant leptin or PBS s.c., rats receiving leptin had a $17 \%$ higher DTH response than rats receiving PBS. The isolated splenocytes from the former group also proliferated $34 \%$ more in vitro in response to the mitogen concanavalin A as compared with the latter group. These results suggest that peripheral leptin has a dominant role in maintaining $\mathrm{T}$-cell-mediated immune responses in rats, and central leptin is unable to compensate for the immunosuppression associated with peripheral hypoleptinemia. Furthermore, preservation of normal cell-mediated immune responses does not require fat tissue as along as serum leptin levels are maintained.

Journal of Endocrinology (2002) 174, 455-461

\section{Introduction}

Leptin, the $o b$ gene product, is one indicator of the quantity of fat storage (Zhang et al. 1994, Ahima \& Flier 2000). This adipocyte-derived hormone regulates whole body energy balance through its dual effects on food intake and energy expenditure (Friedman \& Halaas 1998, Ahima $\&$ Flier 2000). More recently, leptin was shown to directly stimulate murine T-lymphocyte immune activity (Lord et al. 1998). Considering that leptin is structurally related to the long-chain helical cytokine family, and its receptors are one member of the hematopoietic cytokine receptor family (Fruhbeck et al. 2001), it is not surprising that leptin impacts T-cell functions. Diminished leptin levels associated with starvation or malnutrition result in immunosuppression including a reduced delayed-type hypersensitivity $(\mathrm{DTH})$ response and lowered in vitro mitogenic proliferation in mice (Lord et al. 1998). Peripheral leptin replacement can effectively reverse these immunosuppressive effects (Lord et al. 1998). Leptin administration also protects normal mice from starvation-induced lymphoid atrophy (Howard et al. 1999), and chronic leptin deficiency produces decreased T-helper 1 (Th1) cell responses and increased Th2 cell responses (O'Neill 2001). Leptin, therefore, provides one important link between nutritional state and T-cell functions.

The effects of leptin on food intake and energy expenditure are primarily mediated by the central nervous system (CNS) (Campfield et al. 1995, Stephens et al. 1995, Vaisse et al. 1996). Leptin enters specific regions in the brain, in particular the hypothalamus, interacts with its receptors, and subsequently activates specific neuroendocrine pathways (Campfield et al. 1995, Stephens et al. 1995, Vaisse et al. 1996). Evidence also points to direct actions of leptin on some peripheral tissues such as white adipose tissue, liver and pancreas (Shimabukuro et al. 1997, SiegristKaiser et al. 1997, Ookooma et al. 1998). Some of these actions, however, may still require participation of the 
CNS (Koyama et al. 1998). The direct stimulation of lymphocytes by leptin is presumably mediated by the long-form functional leptin receptor residing on the surface of T cells (Lord et al. 1998), but it is not clear whether central effects of leptin also influence T-cell immune responses. Although acute central leptin administration suppresses splenic lymphocyte functions in rodents (Okamoto et al. 2000), little is known thus far about how chronic central leptin therapy relates to peripheral immunity.

We previously reported that application of central leptin gene therapy through recombinant adeno-associated virus (rAAV) prevents growth related weight gain in young F344 $\times$ BN rats (Scarpace et al. 2002). This benign virus containing the rat leptin coding sequence is injected directly into the third ventricle, resulting in a near complete loss of fat mass by 40 days post injection. The disappearance of the fat mass is accompanied by an elevation in cerebral spinal fluid (CSF) leptin due to unabated central leptin transgene expression, whereas serum leptin is correspondingly reduced to below the detection limit because of near zero adiposity level. This unusual scenario, i.e. augmented CSF leptin vs undetectable circulating leptin, has permitted us to address whether peripheral or central leptin is more important in maintaining the T-cell-mediated immune responses.

To address this question, we first examined the DTH response in $\mathrm{F} 344 \times \mathrm{BN}$ rats that underwent a $48 \mathrm{~h}$ fast with or without peripheral leptin replacement. Secondly, we compared the DTH response of the rats receiving central rAAV-leptin gene therapy with the rats receiving only control vector. Thirdly, we investigated the effect of peripheral leptin supplementation on the DTH response and mitogenic activity of the splenic lymphocytes following central rAAV-leptin-induced hyperleptinorrachia. We found peripheral but not central leptin is essential for maintaining $\mathrm{T}$-cell immune functions in rats.

\section{Materials and Methods}

\section{Animals}

Three-month-old male F344 $\times$ Brown Norway $($ F344 $\times$ BN) rats were purchased from Harlan Sprague-Dawley (Indianapolis, IN, USA) under contract with the National Institute on Aging. Rats were housed individually under controlled temperature with a $12 \mathrm{~h}$ light: $12 \mathrm{~h}$ darkness cycle (0700-1900 h) and allowed free access to a regular laboratory chow and water. The care and use of the animals were in accordance with the principles of the Guide to the Care and Use of Experimental Animals and approved by the local Institutional Animal Care Committee. The animals remained in quarantine for either 2 days before fasting or 1 week before administration of rAAV-leptin.

\section{Preparation of $r A A V$ vectors}

The construction and packaging of rAAV vectors were described in detail elsewhere (Zolotukhin et al. 1999). Briefly, leptin gene is under the control of the chicken $\beta$-actin promoter that is connected to a CMV enhancer. A 'humanized' green fluorescent protein reporter gene is linked to leptin for coordinate expression and detection. The titer of rAAV-leptin vector used in this study was $1 \cdot 38-8 \cdot 28 \times 10^{13}$ physical particles/ml with a ratio of physical to infectious particles of 29 .

\section{Administration of rAAV-leptin vectors}

Rats were given a single dose $\left(1.4-8.5 \times 10^{9}\right.$ infectious particles in 3-5 $\mu$ l) of either control vector or $\mathrm{AAAV}$-leptin by intracerebroventricular injection into the third cerebral ventricle (Scarpace et al. 2002). Rats were handled daily (starting one week before rAAV-leptin delivery and continuing from the time of delivery) for body weight $(\mathrm{BW})$ and food intake measurement. The DTH response experiment was performed 60 days after rAAV-leptin administration.

\section{Rodent fasting}

Three groups of rats were included in this experiment and all were mock injected twice daily with PBS for 2 days before initiation of the experiment. Whereas rats in the control group had free access to food, the other two groups were fasted for $48 \mathrm{~h}$ during which period they received twice-daily i.p. injections of either PBS for the Fasted-PBS group or recombinant murine leptin $(1 \mu \mathrm{g} / \mathrm{g} \mathrm{BW})$ for the Fasted-leptin group. The first i.p. injection was given just prior to food withdrawal. The control rats also received PBS administration in the similar fashion. After $48 \mathrm{~h}$, the fasted rats were allowed free access to food.

\section{Measurement of the DTH response}

The DTH response was assessed according to Dhabhar \& McEwen (1999). Briefly, rats were sensitized on two consecutive days by applying $100 \mu \mathrm{l} \quad 1 \% \quad(\mathrm{w} / \mathrm{v}) \quad 2,4-$ dinitrofluorobenzene (DNFB) (Sigma) in acetone/olive oil $(4: 1 \mathrm{v} / \mathrm{v})$ to the plucked dorsum $(3 \times 4 \mathrm{~cm}$ area $)$. Five days later, $50 \mu \mathrm{l} 0.5 \%$ DNFB were applied to the dorsal surface of the right pinnae of all animals while $50 \mu \mathrm{l}$ of vehicle were placed onto the left ear. Ear thickness of the same relative region was measured with a hand-held micrometer at specified times after rats were challenged. The sensitization was performed during the period of fasting in the starvation experiment.

\section{Blood collection from tail vein}

Conscious rats were placed in plastic cones. A $\sim 3 \mathrm{~mm}$ piece was removed from the end of the tail with a razor 
blade. The rat was held straight up and the tail was hanging naturally. The tail was massaged gently from the base all the way to the tip and the blood collected drop-wise in a $1.5 \mathrm{ml}$ microcentrifuge tube until reaching $\sim 500 \mu \mathrm{l}$ in volume. A silver nitrate applicator (silver nitrate $75 \%$, potassium nitrate $25 \%$; local distributor) was then used to stop further bleeding from the tail.

\section{Implantation of mini-pumps}

Mini-osmotic pumps (Alzet Model 2001; DURECT Corp., Cuperfino, CA, USA) were filled with either PBS or murine recombinant leptin in $\mathrm{PBS}(4 \mu \mathrm{g} / \mu \mathrm{l})$ and primed in $0.9 \% \mathrm{NaCl}$ at $37{ }^{\circ} \mathrm{C}$ overnight. The maximum pump volume was $200 \mu \mathrm{l}$ and the solution was delivered at a rate of $1 \mu \mathrm{l} / \mathrm{h}$ over a 1 week period. Rats were anesthetized with ethrane and the pump was implanted s.c. on the dorsal side.

\section{Lymphocyte proliferation assay (concanavalin $A$ (Con A) response)}

A splenocyte suspension was prepared according to Smialowicz (1995) with modifications. Basically, each spleen was placed in $10 \mathrm{ml}$ cold RPMI-1640 medium (Gibco) supplemented with 5\% heat-inactivated fetal bovine serum and $50 \mu \mathrm{g} / \mathrm{ml}$ gentamicin (complete medium), and then gently disrupted by pressing through a metal mesh using a flat-bottomed glass rod. Lymphocytes were collected by centrifugation after erythrocyte lysis and several washing cycles, and finally resuspended at $1 \times 10^{6}$ cells $/ \mathrm{ml}$ in complete medium supplemented with $50 \mu \mathrm{M}$ $\beta$-mercaptoethanol (reduced medium). Flat-bottomed microtiter 96-well plates were set up with either $100 \mu \mathrm{l} /$ well reduced medium alone for background control, or 50000 cells $/ 100 \mu \mathrm{l}$ per well with or without $8 \mu \mathrm{g} / \mathrm{ml}$ Con A mitogen (Sigma). The plates were kept at $37^{\circ} \mathrm{C}$ for $72 \mathrm{~h}$ in a humidified incubator with $5 \% \mathrm{CO}_{2}$. The CellTiter 96 Aqueous One Solution Reagent (Promega) was then added at $20 \mu \mathrm{l} /$ well, and the plates were further incubated for $4 \mathrm{~h}$ under the same conditions, and the absorbance at $490 \mathrm{~nm}$ was recorded using a 96-well plate reader.

\section{Serum leptin analysis}

Serum leptin levels were measured using a Linco Rat Leptin RIA kit (Linco Research, St Charles, MO, USA) following the procedures recommended by the manufacturer. The lower detection limit of the assay is $0.5 \mathrm{ng} / \mathrm{ml}$ of serum or plasma leptin.

\section{Results}

\section{Peripheral leptin prevents fasting-induced immunosuppression}

The effect of peripheral leptin replacement in response to fasting was determined in this experiment. By the end of a $48 \mathrm{~h}$ fast, the rats had lost $\sim 7 \cdot 4 \%$ of initial BW (Fig. 1).

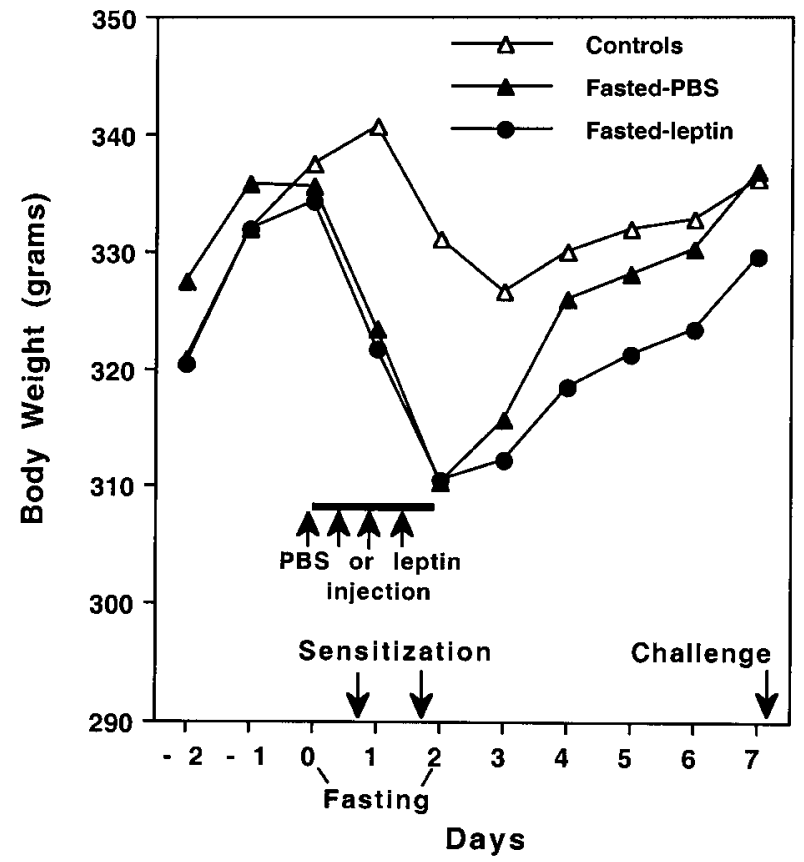

Figure 1 The effect of a $48 \mathrm{~h}$ fast on BW of male $\mathrm{F} 344 \times \mathrm{BN}$ rats. Values represent the mean of five or six rats per group $(n=6$, control and Fasted-leptin rats; $n=5$, Fasted-PBS rats). The $48 \mathrm{~h}$ fasting period from day 0 to day 2 is indicated. All three groups received i.p. injections of either PBS or leptin $(1 \mu \mathrm{g} / \mathrm{g}$ BW) immediately before fasting, and twice daily during the course of fasting, as indicated by the arrows. All the animals were sensitized with DNFB on day 1 and day 2, and then were challenged with DNFB on day 7. (To ensure clarity of the figure, error bars are not included.)

Some experimental procedures, such as ethrane anesthesia and application of the skin irritant DNFB, caused a small degree of weight loss in control rats even though they were allowed to feed ad libitum (Fig. 1). Fasting significantly reduced serum leptin to one-quarter of that of the controls (Table 1), whereas twice-daily i.p. injections of recombinant murine leptin $(1 \mu \mathrm{g} / \mathrm{g} \mathrm{BW})$ to fasted rats (Fasted-leptin rats) maintained serum leptin level above $10 \mathrm{ng} / \mathrm{ml}$ (Table 1). Upon completion of the 2-day fast, the fasted animals resumed free access to food, and the serum leptin levels in these rats correspondingly returned to the same levels as in control rats at the end of the DTH study (Table 1). Following the DNFB challenge on day 7 , the control and Fasted-leptin rats showed a similar extent of pinna swelling at both 6 and $24 \mathrm{~h}$ post challenge. In contrast, the DTH response of the fasted rats administered PBS (Fasted-PBS rats) was only 10\% of that of Fastedleptin rats at $6 \mathrm{~h}$, although at $24 \mathrm{~h}$, pinna swelling increased to $84 \%$ (Fig. 2). If the values of the right pinna thickness of the fasted rats were considered individually, all six Fasted-leptin rats displayed right pinna swelling by $6 \mathrm{~h}$, whereas three out of five Fasted-PBS rats experienced no pinna swelling during the same period, indicating that 
Table 1 Peripheral leptin replacement prevents fasting-induced decrease in serum leptin. Data represent the means \pm S.E. of six control, six Fasted-leptin and five Fasted-PBS rats. Leptin $(1 \mu \mathrm{g} / \mathrm{g} \mathrm{BW})$ was provided twice a day only during the 2-day fasting period to the leptin treatment group

\begin{tabular}{|c|c|c|c|}
\hline \multirow[b]{3}{*}{ Treatment } & \multirow[b]{2}{*}{ Food consumption } & \multicolumn{2}{|c|}{ Serum leptin (ng/ml) } \\
\hline & & $\begin{array}{l}\text { End of the } 48 \mathrm{~h} \\
\text { dieting period }\end{array}$ & $\begin{array}{l}\text { Completion of the } \\
\text { DTH study }\end{array}$ \\
\hline & & & \\
\hline Control & Ad libitum & $2 \cdot 40 \pm 0 \cdot 26$ & $3 \cdot 15 \pm 0 \cdot 63$ \\
\hline PBS & Fasted & $0 \cdot 59 \pm 0 \cdot 20^{*}$ & $2 \cdot 08 \pm 0 \cdot 50$ \\
\hline Leptin & Fasted & $12 \cdot 27 \pm 1 \cdot 84^{*}$ & $1 \cdot 44 \pm 0 \cdot 30$ \\
\hline
\end{tabular}

${ }^{*} P=0.0002$ for the difference between Fasted-PBS and control rats, $P=0.0004$ for the difference between Fasted-PBS and Fasted-leptin rats, and $P=0.0001$ for the difference with treatments by one-way ANOVA.

diminished serum leptin delayed the onset of the T-cellmediated DTH response. Taken together, these data suggest that replenishment of circulating leptin during the period of fasting prevents fasting-induced immunosuppression in rats.

\section{Elevation of CSF leptin fails to maintain the T-cell-mediated DTH response}

To evaluate whether high central leptin levels can maintain the normal DTH response in the presence of

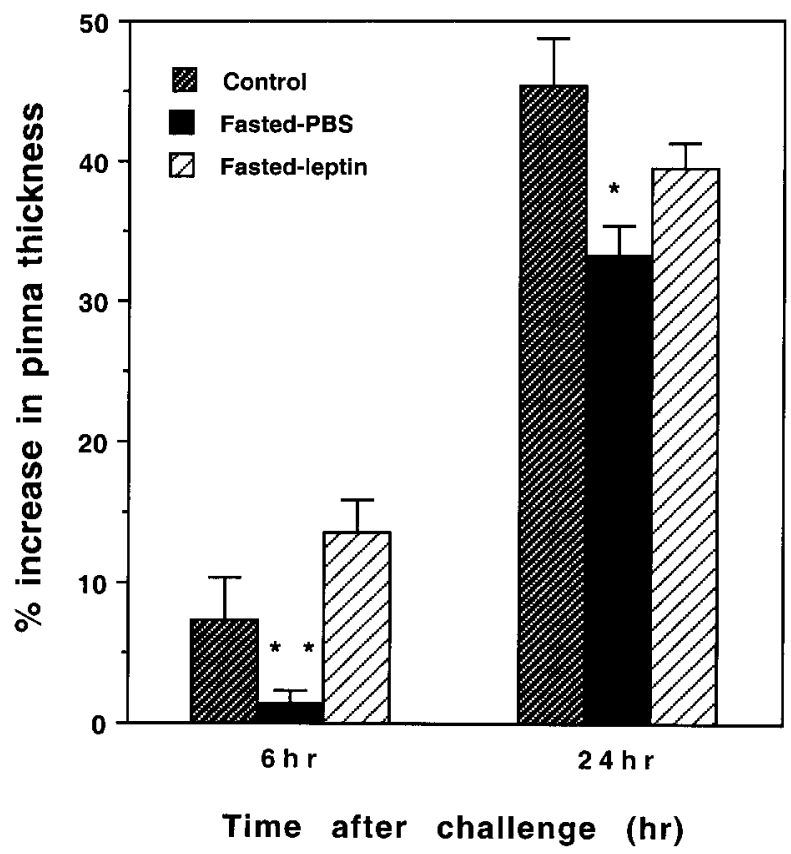

Figure 2 Peripheral leptin replacement maintains normal DTH response in fasted rats. Data represent the means \pm S.E. of five or six rats per group. $P=0.007(6 \mathrm{~h})$ and $P=0.009(24 \mathrm{~h})$ for difference with treatments by one-way ANOVA. ${ }^{* *} P=0.001$ for difference between Fasted-PBS and Fasted-leptin rats at $6 \mathrm{~h}$, and ${ }^{*} P=0.03$ for difference between Fasted-PBS and Fasted-leptin rats at $24 \mathrm{~h}$. The DTH response measured at both time points showed no statistical difference between the control and Fasted-leptin rats $(P>0 \cdot 05)$. peripheral hypoleptinemia, we compared the DTH response of the rats given central rAAV-leptin for 60 days with the rats given rAAV control vector. At day 60, in contrast to the plentiful amount of fat mass in all fat depots in the control rats, there was no visible body fat remaining in the rAAV-leptin rats. The serum leptin levels in these rats were less than $0.5 \mathrm{ng} / \mathrm{ml}$ (the detection limit of the RIA). In a separate but related study (Scarpace $e t$ al. 2002), leptin levels in CSF of both the control and rAAV-leptin rats that had undergone gene therapy for the same length were measured after killing. The rAAV-leptin rats had nearly a 2 -fold higher CSF leptin $(175 \pm 25 \mathrm{pg} / \mathrm{ml})$ compared with control rats $(100 \pm 8 \mathrm{pg} / \mathrm{ml})$. The rAAV-leptin rats, therefore, have central hyperleptinorrachia but peripheral hypoleptinemia. Following a challenge with DNFB, the DTH response of the rAAV-leptin rats was lower throughout the entire $74 \mathrm{~h}$ time course post challenge, and the biggest difference amounted to a 10-20\% decrease from control rats between 20 and $36 \mathrm{~h}$ (Fig. 3). Thus, central hyperleptinorrachia in rats with peripheral hypoleptinemia failed to maintain the T-cell-mediated DTH response.

The immunoenhancing effect of peripheral leptin is not obscured by central hyperleptinorrachia

To determine whether peripheral leptin replacement can enhance T-cell functions following induction of CSF leptin, two groups of rats both undergoing central rAAVleptin treatment were given either s.c. infusion of PBS (PBS group) or recombinant murine leptin (leptin group). The DTH response and the splenic lymphocyte proliferative response to Con A were then compared between the groups. Again, 60 days of central rAAV-leptin treatment produced a near complete depletion of the body fat and a corresponding decrease in serum leptin to an undetected level (Table 2). However, the s.c. mini-osmotic pump delivery of recombinant leptin raised circulating leptin into the physiological range (Table 2). These data confirmed the effectiveness of the s.c. infusion of leptin at 


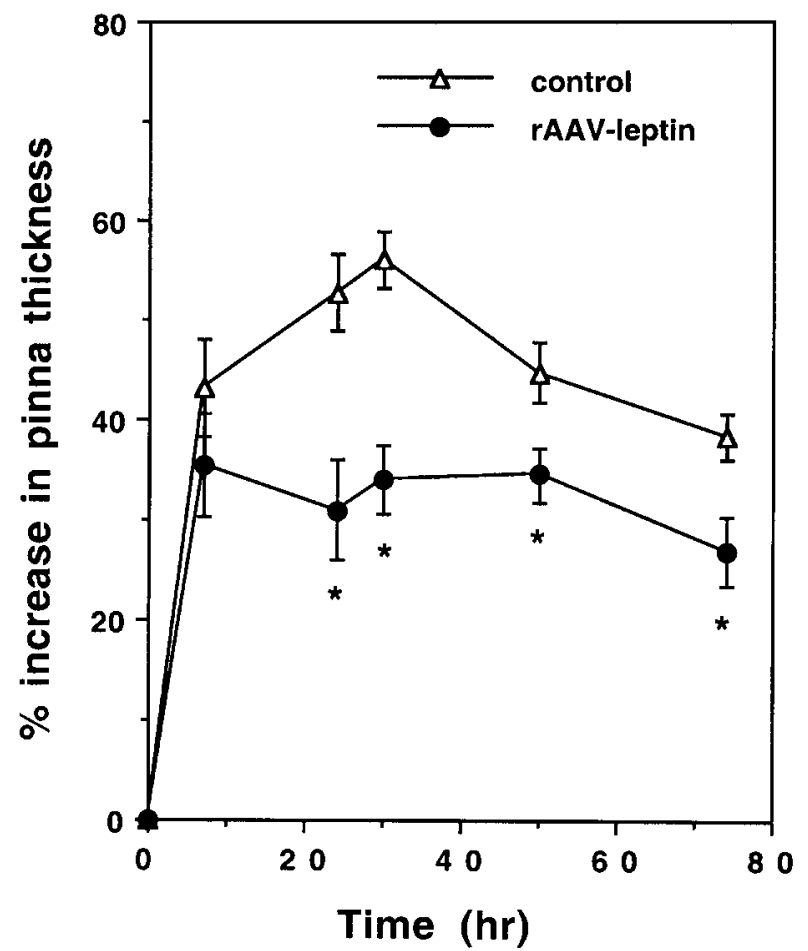

Figure 3 Central rAAV-leptin gene therapy results in an impaired DTH response. A $74 \mathrm{~h}$ time course of changes in the right pinna thickness of previously sensitized rats is presented. Data represent the means \pm S.E. of four or five rats per group $(n=5$, control rats; $n=4$, rAAV-leptin rats). Rats with central rAAV-leptin treatment displayed a significant decrease in the DTH response compared with rats administered control vector. $P=0.0001$ for difference with rAAV-leptin treatment by repeated measures. ${ }^{*} P<0.05$ for difference between the rAAV-leptin and control rats by post-hoc analysis.

$0.1 \mathrm{mg} /$ day in restoring serum leptin levels. After receiving exogenous peripheral leptin replacement, the leptin rats displayed a $17 \%$ stronger DTH response at $24 \mathrm{~h}$ post challenge compared with the PBS rats (Fig. 4A). Although the unstimulated $\mathrm{T}$ lymphocytes from either the PBS or leptin-infused rAAV-leptin rats proliferated to a similar extent (data not shown), the stimulated $\mathrm{T}$ lymphocytes of the leptin-infused rats in response to Con A exhibited 34\% higher mitogenic proliferation (Fig. 4B). These data demonstrate that peripheral leptin enhances $\mathrm{T}$-cell immune activity in rats that are both fat-depleted and have central hyperleptinorrachia.

\section{Discussion}

Leptin is one modulator of immune functions in mice. Lord et al. (1998) demonstrated that starvation induces immunosuppression in mice and peripheral leptin replacement restores immune responses. Such studies have not been reported for rats. Rats weigh substantially more than age-matched mice and lose much less weight for the same fasting period. For example, by the end of the $48 \mathrm{~h}$ fast in this study, the F344 $\times$ BN rats lost only $\sim 7 \cdot 4 \%$ of initial $\mathrm{BW}$, whereas the mice used in Lord's study lost close to $30 \%$ of initial BW. These animals, therefore, may respond differently to nutritional deprivation and exogenous leptin administration. Nonetheless, our findings are consistent with published data in that fasting in rats induces immunosuppression and peripheral leptin replacement restores T-cell functions. During the period of the first $6 \mathrm{~h}$ after challenge in this study, only two out of five Fasted-PBS rats had evidence of pinna swelling, whereas swelling appeared in all six Fasted-leptin rats. By 24 h, however, pinna swelling in Fasted-PBS rats reached $~ 84 \%$ of that of Fasted-leptin rats. Thus, diminished serum leptin associated with fasting in our rat model appears to delay the onset of the DTH reaction rather than alter the magnitude of the response. It is not clear whether this would be the case in mice because only one measurement at $24 \mathrm{~h}$ post challenge was reported in the previous study with fasted mice (Lord et al. 1998).

The kinetics of the DTH response was apparently different depending upon whether this immune reaction was associated with transient peripheral leptin deficiency or chronic leptin deficiency. In the case of transient leptin deficiency, pinna thickness of Fasted-leptin rats was already substantially greater than that of Fasted-PBS rats $6 \mathrm{~h}$ after challenge (Fig. 2). In the case of chronic leptin deficiency (rAAV-leptin rats), however, it was not until $20 \mathrm{~h}$ after challenge that there was a significant difference in pinna swelling between the rAAV-leptin rats and controls (Fig. 3). Examination of the physiology of these experimental rats may provide a possible explanation for such a difference in the DTH reaction. The rAAV-leptin rats have stable but near zero serum leptin levels associated with the depletion of body fat, whereas Fasted-PBS rats have only transiently reduced serum leptin levels, and the body fat in these rats is still plentiful compared with the rAAV-leptin rats. Considering these physiological distinctions, it is not hard to imagine that these animals may display DTH responses with different kinetics and magnitude.

Fasting-induced changes in T-cell responses are presumably due to changes in serum leptin. However, when serum leptin levels fluctuate in response to an everchanging nutritional status of an animal, CSF leptin levels alter accordingly. Thus, it is unclear whether peripheral leptin, central leptin, or both together affect T-cell functions. Furthermore, if both peripheral and central leptin can impact T-lymphocyte functions, are the effects additive, synergistic or opposing, and does one form of leptin, central or peripheral, have a predominant effect over the other? Although this study did not address all these questions, our long-term central rAAV-leptintreated rats represent an ideal model to address some. In 
Table 2 Mini-pump delivery of leptin restores physiological level of circulating leptin. Data represent the means \pm S.E. of three PBS and three leptin rats administered rAAV-leptin for 60 days

\begin{tabular}{|c|c|c|c|}
\hline & \multicolumn{3}{|l|}{ Serum leptin (ng/ml) } \\
\hline & $\begin{array}{l}\text { Before rAAV-leptin } \\
\text { treatment }\end{array}$ & rAAV-leptin (60 days) & $\begin{array}{l}\text { End of the 7-day leptin } \\
\text { or PBS infusion }\end{array}$ \\
\hline rAAV-leptin; PBS & $2 \cdot 61 \pm 0.95$ & $<0 \cdot 5^{*}$ & $<0 \cdot 5^{*}$ \\
\hline rAAV-leptin; leptin & $1.93 \pm 0.68$ & $<0 \cdot 5^{*}$ & $9 \cdot 27 \pm 2 \cdot 51$ \\
\hline
\end{tabular}

*The 60-day central rAAV-leptin therapy induced a depletion of body fat in both the PBS and leptin rats; as a consequence, the serum leptin levels in these rats were below the detection limit.

\section{A}

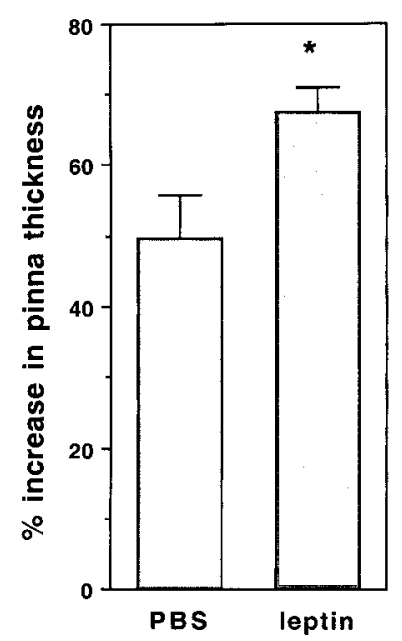

B

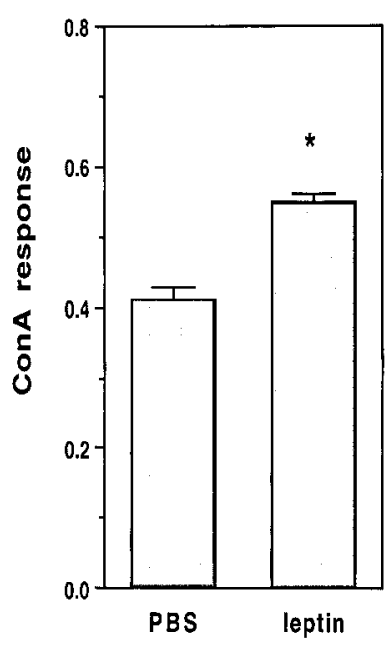

Figure 4 Peripheral leptin enhances cell-mediated immune responses in rats with central rAAV-leptin therapy. Data represent the means \pm S.E. of three rats per group. Both the PBS and leptin groups had received central rAAV-leptin treatment for 60 days, and were then given either PBS or murine recombinant leptin $(0.1 \mathrm{mg} /$ day $)$ by s.c. mini-pump delivery $2 \mathrm{~h}$ before the initiation of the immune function study and for the remaining 8 days over the course of the study. The leptin-treated rats showed significant increases in both the DTH response at $24 \mathrm{~h}$ post challenge (A) and the degree of lymphocyte proliferation in response to mitogen Con A stimulation (B). ${ }^{*} P=0.04$ (A) and $P=0.01$ (B) for difference between the leptin and PBS rats by Student's $t$-test.

these rats, CSF leptin is increased by nearly 2 -fold over the control animals, whereas serum leptin remains undetected over the duration of the experiment. Such a model allows us to separate, at least partially, the contribution of central and peripheral leptin to the regulation of T-lymphocyte functions.

There are three salient findings from this study. First, T-cell functions correlate with peripheral leptin levels. When serum leptin is reduced to below the detection limit, the DTH response correspondingly diminishes. When serum leptin is replenished to physiological levels by leptin replacement, both the DTH response and mitogenic activity of splenic lymphocytes are enhanced. Secondly, elevation in CSF leptin fails to maintain T-cell

immune responses. The near 2-fold higher CSF leptin is unable to compensate for the immunosuppression associated with fat depletion and peripheral hypoleptinemia. This observation suggests that either central leptin has little effect on lymphocyte functions, or its effect, whether positive or negative, is trivial compared with the predominant immunoenhancing effect of peripheral leptin. Thirdly, the maintenance of normal cell-mediated immune responses does not require the presence of fat tissues. T lymphocytes are stimulated with peripheral leptin replacement in the rAAV-leptin-treated rats that have basically no body fat. This last finding is rather unexpected. It points to the potential clinical application of using leptin supplementation to preserve a normal immune system in human subjects who experience a substantial loss of body fat resulting in diminished serum leptin. In summary, our data indicate that peripheral rather than central leptin is necessary to maintain T-cellmediated immune responses.

\section{Acknowledgements}

This work is supported by the Medical Research Service of the Department of Veterans Affairs and National Institute on Aging Grant AG-17047.

\section{References}

Ahima RS \& Flier JS 2000 Leptin. Annual Reviews in Physiology 62 413-437.

Campfield LA, Smith FJ, Guisez Y, Devos R \& Burn P 1995 Recombinant mouse ob protein: evidence for a peripheral signal linking adiposity and central neural networks. Science 69 546-549.

Dhabhar FS \& McEwen BS 1999 Enhancing verses suppressive effects of stress hormones on skin immune function. PNAS 96 1059-1064.

Friedman JM \& Halaas JL 1998 Leptin and the regulation of body weight in mammals. Nature 395 763-770.

Fruhbeck G, Gomez-Ambrosi J, Muruzabal FJ \& Burrell MA 2001 The adipocyte: a model for integration of endocrine and metabolic signaling in energy metabolism regulation. American Journal of Physiology. Endocrinology and Metabolism 280 E827-E847.

Howard JK, Lord GM, Matarese G, Vendetti S, Ghatei MA, Ritter MA, Lechler RI \& Bloom SR 1999 Leptin protects mice from 
starvation-induced lymphoid atrophy and increases thymic cellularity in ob/ob mice. Journal of Clinical Investigation 104 1051-1059.

Koyama K, Shimabukuro M, Chen GX, Wang MY, Lee Y, Kalra PS, Dube MG, Kalra SP, Newgard CB \& Unger RH 1998 Resistance to adenovirally induced hyperleptinemia in rats (comparison of ventromedial hypothalamic lesions and mutated leptin receptors). Journal of Clinical Investigation 102 728-733.

Lord GM, Matarese G, Howard JK, Baker RJ, Bloom SR \& Lechler RI 1998 Leptin modulates the T-cell immune responses and reverses starvation-induced immunosuppression. Nature 394 897-901.

Okamoto S, Irie Y, Ishikawa I, Kimura K, Masayuki S 2000 Central leptin suppresses splenic lymphocyte functions through activation of the corticotropin-releasing hormone-sympathetic nervous system. Brain Research 855 192-197.

O'Neill L 2001 A role for leptin in autoimmunity? Trends in Pharmacological Sciences 22341.

Ookooma M, Ookooma K \& York DA 1998 Effects of leptin on insulin secretion from isolated rat pancreatic islets. Diabetes 47 219-223.

Scarpace PJ, Matheny MM, Zhang Y, Tumer N, Frase CD, Shek EW, Hong B, Prima V \& Zolotukhin S 2002 Central leptin gene delivery evokes persistent leptin signal transduction in young and aged-obese rats but physiological responses become attenuated over time in aged-obese rats. Neuropharmacology 42 549-562.

Shimabukuro M, Koyama K, Chen GX, Wang MY, Trieu F, Lee Y, Newgard CB \& Unger RH 1997 Direct antidiabetic effect of leptin through triglyceride depletion of tissues. PNAS $\mathbf{9 4}$ 4637-4641.
Siegrist-Kaiser CA, Pauli V, Juge-Aubry CE, Boss O, Pernin A, Chin WW, Cusin I, Rohner-Leanrenaud F, Burger AG, Zapf J \& Meier CA 1997 Direct effects of leptin on brown and white adipose tissue. Journal of Clinical Investigation 100 2858-2864.

Smialowicz RJ 1995 In vitro lymphocyte proliferation assays: the mitogen-stimulated response and the mixed-lymphocyte reaction in immunotoxicity testing. In Methods in Immunotoxicology, vol 1, pp 197-210. Eds GR Burleson, JH Dean \& AE Munson. New York: Wiley-Liss.

Stephens TW, Basinski M, Bristow PK, Bue-Valleskey JM, Burgett SF, Craft L, Hale J, Hoffmann J, Hsiung HM \& Kriauciunas A 1995 The role of neuropeptide $\mathrm{Y}$ in the antiobesity action of the obese gene product. Nature 377 530-532.

Vaisse C, Halaas JL, Horvath CM, Darnell JE Jr, Stoffel M \& Friedman JM 1996 Leptin activation of STAT3 in hypothalamus of wide-type and ob/ob mice but not db/db mice. Nature Genetics 14 95-97.

Zhang Y, Proenca R, Maffei M, Barone M, Leopold L \& Friedman JM 1994 Positional cloning of the mouse obese gene and its human homologue. Nature 372 425-432.

Zolotukhin S, Byrne BJ, Mason E, Zolotukhin I, Potter M, Chesnut K, Summerford C, Samulski RJ \& Muzyczka N 1999 Recombinant adeno-associated virus purification using novel methods improves infectious titer and yield. Gene Therapy 6 973-985.

Received in final form 8 May 2002

Accepted 23 May 2002 